IRSH 52 (2007), pp. 57-87 DOI: I0.I0I7/S002085900600278 I

(C) 2007 Internationaal Instituut voor Sociale Geschiedenis

\title{
Breadwinners and Dependants: Working-Class Young People in England, r918-i955
}

\author{
SELINA TODD
}

Summary: The prevailing image of twentieth-century English "youth" is as a triumphal signifier of affluent leisure consumption. By contrast, this article demonstrates the importance of young working-class people's economic role as wage-earners in the mid-twentieth century. This shaped their treatment by the family and the state and the life histories of the adults they became. Juveniles were crucial breadwinners in interwar working-class households. However, the consequences of high unemployment among adult males helped redefine youth as a period of state protection and leisure in the post-1945 decades. Nevertheless, personal affluence remained limited, and young people's economic responsibilities high, until at least the mid-I950s. The history of twentieth-century youth is best understood as one in which young working-class people's fortunes were closely linked to their family's circumstances and their importance as a supply of cheap labour. Social class thus formed, and was formed by, the experience and memory of being young.

The historian's gaze is generally drawn to the alluring images of affluent mid-twentieth century youth - the pleasure-loving flappers of the interwar years, ${ }^{\mathrm{I}}$ the Teddy Boys emerging in the $1950{ }^{2}{ }^{2}$ Yet what links these two groups more fundamentally than fashion is the prosaic importance of work in shaping their lives. The growth of teenage affluence, particularly in the postwar decades, was defined against, yet relied upon, the youthful wage-earner. A tension between dependence on, and contributing to, the family marked the experience of youth, as high unemployment and the operation of the household means test demonstrated in the early 1930s. Working-class affluence masked the extent to which this remained the case between the late i950s and late i960s, but youth unemployment and a rise in poverty between the I970s and I990s

I. J. Bourke, Working-Class Cultures in Britain 1890-1960: Gender, Class and Ethnicity (London, 1994), pp. 45-46; D. Fowler, The First Teenagers: The Lifestyle of Young Wage-Earners in Interwar Britain, (London, I995), pp. 8-1 I, I 59-165; A. Davies, Leisure, Gender, Poverty: Working-Class Cultures in Manchester and Salford, 1900-1939, (Buckingham, 1992), pp. 83-89; C. Langhamer, Women's Leisure in England 1920-1960 (Manchester, 2000), pp. 101-103.

2. B. Osgerby, Youth in Britain since 1945 (Oxford, 1998). 
illustrated that young people remained a pool of unskilled labour, available because of family need for their earnings, but whose insecure and low-paid employment ultimately rendered them reliant on parental support. ${ }^{3}$

Although the working-class affluent teenager occupied only a fleeting postwar decade, this image has shaped historical and sociological understandings of youth. ${ }^{4}$ David Fowler has argued that interwar England witnessed the emergence of "the first teenagers" and emphasizes the role of commercial leisure in this alleged development.5 This is unfortunate, since the term "teenager" was used first in the I950s. More historically sensitive accounts are offered by Claire Langhamer and Bill Osgerby, which point to a significant, postwar increase in luxury consumption. ${ }^{6}$ However, studies of youth, structured as they are by comparison with the affluent teenager of the I960s, focus primarily on leisure. Perhaps this focus is also explained by the emotive linkage of childhood to paid work; it is still difficult to find ways of writing about young people at work outside the framework of "conventional horror and pity"7 adopted by nineteenthcentury social investigators.

Existing accounts do not pay particular attention to the political and economic construction of youth, concentrating almost exclusively on leisure experience and cultural representation. This article argues that "youth" is a subjective life stage, the existence and definition of which was a site of political and economic, as well as social and cultural contestation during the mid-twentieth century. This is demonstrated by the political and popular uncertainty about, and attempts to define, young people (particularly the young working class). The group focused on here were termed "juveniles" by the state and press before 1939, and were, aged between fourteen years (when compulsory schooling ended) and eighteen years when, in many legal and employment matters, individuals became treated as adults. In the postwar decade, "youth" - which was drawn from the vocabulary of social work and educational agencies, rather than from the labour market and courts - became consciously applied by government, and increasingly widely used by the media and in popular vocabulary - to define the period between fifteen (the school-leaving age from 1948) and eighteen years (the age of conscription into National Service for young men). "Teenager", which became commonly used by the

3. On the I970s, I980s, and I990s, see K. Roberts, Youth and Employment in Modern Britain (Oxford, I995), p. 74; Osgerby, Youth in Britain, pp. I 56-I 57; R. MacDonald et al., "Growing Up in Poor Neighbourhoods: The Significance of Class and Place in the Extended Transitions of 'Socially Excluded' Young Adults", Sociology, 39 (2005), pp. 873-89г.

4. S. Hall and T. Jefferson (eds), Resistance through Rituals: Youth Sub-Cultures in Post-War Britain (London, 1976).

5. Fowler, First Teenagers, pp. ios-i i I, 99.

6. Osgerby, Youth in Britain; Langhamer, Women's Leisure.

7. C. Steedman, Past Tenses: Essays on Writing, Autobiography and History (London, 1992), p. 195 . 
mid-r950s, refers to the same age-group. Prior to World War II, "lads", "young men and women", "flappers", and "girls" were used widely to name both juveniles and men and women in their later teens and early twenties. But by the early i950s the division between "youth" and these older workers was more distinct, due to a falling average age of marriage, conscription, and teenagers' rising wages. This change emphasizes how far economic and social developments affect the definition and contestation of life-stages.

Examining youth in the twentieth century requires consideration of the interplay between their employment, their family responsibilities, yet also their dependence on - and frequently affection for - their parents. Such a framework helps make sense of interwar employers', policymakers', and journalists' definition of working-class juveniles as "pin-money workers", whose earnings were dedicated to leisure expenditure. In I9I9 the War Cabinet Committee on Women in Industry advocated that juveniles should be paid wages below subsistence level, assuming that their parents were able to support them. ${ }^{8}$ The relationship between juveniles' work, wages, and family relations was necessary to the type of economic growth being promoted. "Blind-alley" jobs as delivery boys, messenger girls, or unskilled factory hands employed young people because their supposed dependence on their parents provided a justification for their low wages and insecure employment. 9 Industrial growth in the 1930 s also relied on cheap, juvenile labour. Local education authorities in south-east England, a relatively prosperous region, informed the government that it was inadvisable for unemployed juveniles to migrate to their districts in search of work, because new light manufacturing industries relied on juvenile workers who lived with their parents and would consequently accept low pay. ${ }^{10}$ Juveniles' state benefits were set at significantly lower rates than adults', once again justified by alleged parental support. ${ }^{\text {II }}$ Juveniles were, then, treated paradoxically by the interwar state and labour market. They were primarily represented and treated as dependent on their parents, but there was a silence about the precise reasons why they went out to work at all - namely, family reliance on their earnings, and employers' reliance on cheap labour.

Negotiating this paradox of being a dependant but also a breadwinner was central to growing up working-class in interwar England, and in fact remained so after World War II. After a discussion of the sources available,

8. Report of the War Cabinet Committee on Women in Industry (Parliamentary Papers i919, Cmd I35, xxi. 24I), pp. 6-7.

9. S. Todd, Young Women, Work, and Family in England, I9I8-I950 (Oxford, 2005), ch. I. ı०. The National Archives [hereafter NA], LAB I9/42, Memo I484/I934, ms: "Local Education Authorities which Require Stimulation either by Letter or Interview", I934.

I I. A. Deacon, In Search of the Scrounger (London, 1976), p. 28; T.J. Hatton and R.E. Bailey, "Unemployment Incidence in Interwar London", Economica, 69/276 (2002), pp. 646-648. 


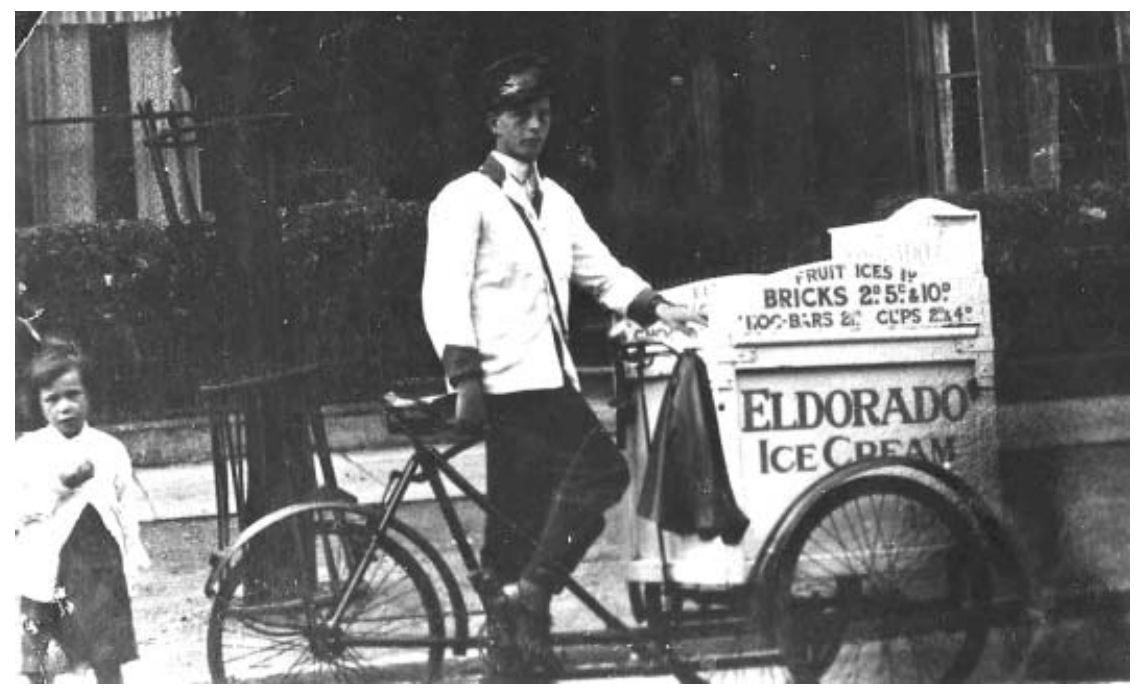

Figure I. A young man selling ice-cream in north Manchester in the mid-I920s. This was one of the "blind-alley" jobs that young men were often employed to do in interwar England. Reproduced by kind permission of Greater Manchester County Record Office

this article will demonstrate that the transition into work was something experienced by most working-class young people - not simply the very poor - due to economic necessity. Intra-household negotiation of juveniles' position, as low-paid dependants, but simultaneously as centrally important to the family economy, is outlined. I then consider how high adult male unemployment in the early I930s, and state responses to this, destabilized these household strategies and prompted legislative reform in the treatment and representation of juveniles. Finally, the continued importance of juveniles in the more affluent later i930s, I940s, and I950s, and what this tells us about the negotiation of individual aspiration and familial wellbeing in attaining and defining affluence, is explored.

This discussion is important not only for what it tells us about the economic and social context of mid-twentieth century England, nor simply for what it says about the relationship between age, gender, and class over this period. It is crucial because the experience of being a son or daughter is more universal than the married state, often taken as the "norm" by social and cultural histories. ${ }^{\mathrm{I}}{ }^{2}$ In the context of this article, that

I2. See for example J. Giles, The Parlour and the Suburb: Domestic Identities, Class, Femininity and Modernity (Oxford, 2004); Bourke, Working-Class Cultures; M. Daunton and M. Hilton (eds), The Politics of Consumption: Material Culture and Citizenship in Europe and America (Oxford, 200I); for an example of work which defines its subjects against this norm see M. Houlbrook, Queer London: Perils and Pleasures in the Sexual Metropolis (Chicago, IL, 2005). 
point is particularly relevant to our understanding of familial breadwinning models. The notion that reliance on a single adult male earner was the norm for working-class households ${ }^{13}$ has still not been fully challenged by historians. Critiques of this thesis have focused on married women's labour force participation. Their employment was certainly significant, particularly during and after World War II, but it was often irregular, prompted by a husband's unemployment or low wages or, by the early I950s, the desire for a particular item of expenditure. ${ }^{14}$ By contrast, young peoples' earnings were a staple of many households' budgets until at least the mid-I950s. As such, their employment patterns provide a fresh perspective on household roles and the relationship between these roles, state intervention, and social identity.

\section{SOURCES}

A major source of data on twentieth-century youth is personal testimony, in the form of retrospective oral history interviews and autobiographies. About sixty archived oral histories and published autobiographies are drawn on here. We are now familiar with the ways that interviewers' rhetorical devices, memory, and popular representations of the past shape an individual's testimony. Is Savage and Miles have pointed out the constraints of the genre of working-class male autobiography; so often tales of self-improvement from a low base, and of ritualized signifiers of childhood poverty. Nevertheless, human agency modifies and adapts linguistic usage; people make their stories, in Steedman's words, "between the cracks". ${ }^{16}$ Undoubtedly the interviewees and authors cited here use particular rhetorical devices, and ways of writing about the self, that are in part derived from existing visual and literary representations of poverty and youth. ${ }^{17}$ But interestingly, in the interviews, information about work and young people's contribution to the family economy is rarely asked for; it tends to be volunteered. ${ }^{18}$

This is significant since the transition from school to work frequently presents the narrator with linguistic and discursive difficulties. One

I 3. J. Giles, Women, Identity and Private Life in Britain, I900-50 (Basingstoke, 1995), pp. 4-5 and 48-49; J. Humphries, "Class Struggle and the Persistence of the Working-Class Family", Cambridge Journal of Economics, I (I977), pp. 24I-258.

I4. T.J. Hatton and R.E. Bailey, "Female Labour Force Participation in Interwar Britain", Oxford Economic Papers, 40 (1988), pp. 7II-7I2; M. Young and P. Willmott, Family and Kinship in East London (Harmondworth, 1962), pp. 177-179; Todd, Young Women, Work, and Family, pp. 70-71.

I 5. P. Thompson, Voice of the Past: Oral History, 3 rd edn (Oxford, 2000); A. Thomson, Anzac Memories (Oxford, 1994).

I6. Steedman, Past Tenses, p. 57.

17. See for example K. Woodward, Jipping Street (London, 1983).

I8. For further discussion of this see Todd, Young Women, Work, and Family, p. I7. 
example of this is given by Dolly's life history, told orally, but published as a book. Despite the problems involved in interpreting an orally transmitted story that has been translated into published text, Dolly's narrative remains interesting and important. She remembers an interwar Manchester childhood that was, in her words, "ordinary". She recognized from an early age that her family - headed by her father, a plumber, and her mother, an irregular seamstress - was poorer than some others in their working-class neighbourhood. This had cultural and social consequences for Dolly. At school, shopkeepers' children "seemed to be at the forefront of things"; "they were just that little bit better dressed". ${ }^{19}$ Thus far, her narrative is fairly unproblematic, with poverty understood as a fact of life imposed from outside the family.

When Dolly left school, however, she became directly implicated in the family's economic circumstances: "I'd been kept until I was I4 [...]. I'd got younger brothers and sisters, and my wage - it was Io shillings a week I'd got to put back into the house [...] to help." ${ }^{20}$ Dolly apparently welcomed the opportunity to help out - but she also recognized that her aid was a non-negotiable necessity. Here, already, is the tension between the understanding of economic inequality, and the feeling that specific family circumstances exacerbated this; a hint that without her siblings, without her parents having those children, Dolly's own life might have been better. For Dolly, as for others of her generation, the transition from school to work was one that was experienced as both ordinary - what everyone did - but also as a moment when the knowledge that poverty limited their choices became acute.

Being a juvenile wage-earner was not simply central to daily life, but also contributed to people's consciousness of their place in society. The significance of youth is grounded not only in its distinctiveness as a lifestage, but also in the ways youthful experience informs adult identity and memory. It is often represented by personal testimonies as a period in which recognition of one's place in society, one's opportunities and limitations, is realized. It is not argued that the remembering of this struggle allows us access to a vision of life as it was lived; but this article does suggest that interviews and autobiographies are themselves influenced and directed by the psychological and cultural consequences of the experience of youth. Their use by historians can shift young people out of the static timelessness of much sociological discussion. They can also help to place young workers in history not as hapless victims of exploitation, or passive recipients of welfare, but as members of a wider working-class community and as agents of historical change. In taking this approach, I draw on Jerry White's study of young people in one interwar London working-class community, which points out that "[a]dolescence and early

19. Lifetimes History Group, Something in Common (Manchester, 1976), p. 27.

20. Ibid., p. 35 . 
adulthood is a time when seminal steps are taken and decisions reached [...] that will affect families and even [...] whole communities." ${ }^{21}$ However, unlike White's book, and most other studies of mid-twentieth century youth, the study presented here takes a national overview, with particular emphasis placed on provincial England.

The comparison of personal testimonies with contemporary social investigations and quantitative data provides a means of understanding and analysing the historical category of experience. Horrell, Humphries, and Oxley have demonstrated that in nineteenth-century England sexual and age-specific divisions of labour were shaped by local opportunities for adult male employment and earnings. ${ }^{22}$ A regression analysis, based on data from the 193 I Census, and laid out in the Appendix (pp. 85-87), tests whether this remained the case in the interwar years. This demonstrates the relative significance of various supply- and demand-side influences on girls', boys', and married women's labour force participation across different urban and rural areas of England. ${ }^{23}$ It offers an insight into why and how decisions about a juvenile's entry to employment were made, and the impact of class, gender, and place upon these. The results are, however, limited. The available data give no information about potentially important supply-side variables like family size at the level of the household. Regional averages are offered, but are too generalized to be of great value. Moreover, differences in census definitions between I92 I and I93 I, and particularly between I93 I and I95 I, prevent a comparison across time. It nevertheless aids analysis of the interrelationship of class, gender, age, and locale in shaping household roles, daily experience, and social identity.

\section{YOUNG PEOPLE AS BREADWINNERS IN INTERWAR ENGLAND}

For the majority of working-class families, a son's or daughter's earnings were crucial to the family economy. Social investigators, like working-

2 I. J. White, Campbell Bunk: The Worst Street in North London Between the Wars (London, I986), p. г6 I.

22. S. Horrell and D. Oxley, "Crust or Crumb?: Intrahousehold Resource Allocation and Male Breadwinning in Late Victorian Britain”, Economic History Review, 52 (1999), pp. 494-522; S. Horrell and J. Humphries, "The Origins and Expansion of the Male Breadwinner Family: The Case of Nineteenth-Century Britain", in Angélique Janssens (ed.), "The Rise and Decline of the Male Breadwinner Family?”, International Review of Social History, 42 (I 997), Supplement 5, pp. 2 5-64. 23. The sample comprises the i Io provincial English urban conurbations which had populations exceeding 50,000, and three rural counties - Northumberland, East Sussex, and West Sussex which matched this population level. Since less than ro per cent of the English population lived in rural areas by $193 \mathrm{I}$, the inclusion of further rural areas would have weighted the data in an unrepresentative manner; together, the three rural counties included here accounted for 5.I per cent of the dataset. The Census does not provide details of earnings, but the Ministry of Labour's "Average Hours and Earnings Enquiry" of 193 I offers data on earnings in that year which are disaggregated by occupation and gender. 
class families, contextualized this within the inadequacies of the father's wage. Despite rising real wages and falling prices, ${ }^{24}$ a substantial proportion of working-class households continued to live in poverty throughout the interwar years. Most contemporary surveys drew on Bowley and Hogg's stringent 1925 calculation that a family of five required a minimum income of $3756 \mathrm{~d}$ per week. ${ }^{25}$ Theirs and subsequent studies found that between 4 per cent and 20 per cent of the working-class population lived in primary poverty. ${ }^{26}$ Rowntree's study of York in 1936 gave the major causes of this, aside from old age, as adult males' low wages and unemployment - causes also identified elsewhere in the country. ${ }^{27}$ Consequently, the life-cycle was crucial in determining a household's probability of poverty; those with children at work were among those least likely to fall below the poverty line. ${ }^{28}$ As a result, a wide range of workingclass households relied on young wage-earners.

Labour force participation did, however, vary according to local labour market. The dataset used in the Appendix demonstrates that across England, a majority of girls and boys were in full-time employment. Married women tended to enter the labour force as a result of exceptionally high local labour demand, combined with male unemployment and/or low male earnings. ${ }^{29}$ In I93 I the national labour force participation rate for adult women ranged from I 2 per cent in Dagenham, where there was plentiful employment for adult men, to 59 per cent in Blackburn, where male unemployment was high and demand for women was strong in the textile industry. Juveniles' participation rates exhibited more limited variance. Girls' rates ranged from 50.5 per cent in Northumberland, where labour demand was high in the traditionally male sectors of mining and agriculture and girls often had to leave home at fourteen to enter domestic service outside the region, ${ }^{30}$ to 89 per cent in Leicester, where the textile trade and light manufacture provided work for them. Boys' participation varied from 69 per cent in Southgate to 92 per cent in Dagenham. ${ }^{\text {I }}$ While married women's labour force participation

24. J. Stevenson, British Society, 1914-1945, (Harmondsworth, 1984), p. I I6.

25. A.L. Bowley and M.H. Hogg, Has Poverty Diminished? (London, I 925 ), pp. I $2-17$.

26. Ibid., pp. I2-I7; H. Llewellyn Smith, New Survey of London Life and Labour [hereafter NSLL] (London, I932), III, pp. 78-96; D. Caradog Jones, The Social Survey of Merseyside (Liverpool, 1934), I, pp. I 56-I60; P. Ford, Work and Wealth in a Modern Port: A Survey of Southampton (London, 1934), pp. I14-116; B.S. Rowntree, Poverty and Progress: A Second Social Survey of York (London, 194I), pp. 30-3 I; H. Tout, The Standard of Living in Bristol (Bristol, 1938), p. 2 I.

27. Rowntree, Poverty and Progress, p. 51; Tout, Standard of Living in Bristol, p. 44.

28. Rowntree, Poverty and Progress, pp. I55-i7i.

29. Hatton and Bailey, "Female Labour Force Participation in Interwar Britain", pp. 695-718.

30. Todd, Young Women, Work, and Family, pp. 58-60.

31. Cambridge and Oxford had far lower participation rates among boys: 44 per cent and 56 per cent respectively, but this was due to the large proportion of university students among I 8 to $20-$ 
varied significantly according to local labour demand and family need, being positively affected by household poverty, juveniles' entry to employment was not determined by unusual levels of poverty, but was a common feature of working-class life wherever labour demand existed for them. They were central to the family economy.

Crucially, the gender differential was much less significant in juveniles' earnings than in adult earnings. Table I shows that there was less variance between male and female earnings among juveniles than among adults. The data probably overstate the difference between boys' and girls' earnings due to the different age ranges employed - while girls were defined as those under eighteen, boys were defined as those under twenty-one, incorporating an extra three years in which their earnings would have risen. Girls could, then, be extremely important as household breadwinners.

Juveniles themselves recognized that their entry to employment was necessitated by family need. Explaining why she had become a domestic servant at the age of fourteen in I929, Edith Edwards simply stated, "we were very, very poor". ${ }^{2}$ Yet even those who were not among the poorest recognized that their earnings were of great benefit for their families. $\mathrm{Mr}$ Pennington was the son of a skilled factory worker who grew up in Liverpool. He became a shop assistant at the age of fourteen, in I92 I. This was an insecure and poorly paid job but "the only one [available] and I didn't like [...] living on my parents". 33 Frank Johnson's father was a skilled manual worker and his mother did casual work, cleaning and taking in washing. He had seven siblings out at work by the time he left school, aged thirteen, in 1924 - he was exempted his final year of schooling by permission of the local education authority because of his good progress. He felt going out to work was the necessary and correct thing for him to do. When asked if he wanted to enter employment, Frank Johnson evaded the question, answering: "I mean I was getting a big lad - you could go out and get a job". 34 These testimonies, like Dolly's, demonstrate that juveniles did not grow up thinking that only adult men were breadwinners in ordinary circumstances, nor that their entry to the labour market was a sign of paternal failure, as some cultural histories have suggested. ${ }^{35}$ Rather, they knew that juveniles were crucial providers for their families, and that

year-olds; the rates for younger juveniles were much nearer the mean for England: 69 per cent in Cambridge and 70 per cent in Oxford.

32. Tameside Local Studies Library [hereafter, TLSL], Manchester Studies Collection, tape no. 36, interview with Edith Edwards.

33. Ibid., tape no. 56, interview with Mr Pennington.

34. Ibid., tape no. 505, interview with Frank Johnson.

35. S. Alexander, "Men's Fears and Women's Work: Responses to Unemployment between the Wars in London", Gender and History, I 2 (2000), pp. 40I-425; Giles, Women, Identity and Private Life in Britain, pp. 39-45. 
Table I. Earnings (shillings) and working hours of workers by age and gender, October 1935.

\begin{tabular}{|c|c|c|c|c|c|c|c|c|}
\hline Industry & $\begin{array}{l}\text { Girls } \\
\text { s/wk }\end{array}$ & $\begin{array}{l}\text { Boys } \\
\text { s/wk }\end{array}$ & $\begin{array}{l}\text { Women } \\
\text { s/wk }\end{array}$ & $\begin{array}{l}\text { Men } \\
\text { s/wk }\end{array}$ & $\begin{array}{l}\text { Girls } \\
\% \text { men's } \\
\text { wage }\end{array}$ & $\begin{array}{l}\text { Boys } \\
\% \text { men's } \\
\text { wage }\end{array}$ & $\begin{array}{l}\text { Women } \\
\% \text { men's } \\
\text { wage }\end{array}$ & $\begin{array}{c}\text { All } \\
\text { Workers } \\
\text { Hrs/wk }\end{array}$ \\
\hline Mining and quarrying (not coal) & 17.91 & 26.50 & 29.58 & 53.33 & 33.58 & 49.69 & 55.47 & 46.40 \\
\hline Treatment of non-metallic quarry products & 17.25 & 28.25 & 29.08 & 60.67 & 28.43 & 46.56 & 47.93 & 48.60 \\
\hline Chemicals, brick, pottery, glass & 15.33 & 24.42 & 29.42 & 63.00 & 24.33 & 38.76 & 46.70 & 47.20 \\
\hline Metals, engineering, shipbuilding & 17.25 & 22.25 & 31.08 & 67.58 & 25.53 & 32.92 & 45.99 & 46.80 \\
\hline Textiles & 17.17 & 23.08 & 30.25 & 55.92 & 30.70 & 41.27 & 54.10 & 47.80 \\
\hline Leather & 15.33 & 22.75 & 29.50 & 61.75 & 24.83 & 36.84 & 47.77 & 47.80 \\
\hline Clothing & 15.00 & 22.42 & 32.67 & 64.50 & 23.26 & 34.76 & 50.65 & 47.00 \\
\hline Food, drink, tobacco & 17.00 & 24.92 & 32.08 & 63.67 & 26.70 & 39.14 & 50.38 & 47.70 \\
\hline Woodworking & 15.58 & 21.92 & 33.83 & 65.08 & 23.94 & 33.68 & 51.98 & 46.90 \\
\hline Paper, printing, stationery etc & 15.50 & 22.92 & 33.42 & 83.67 & 18.53 & 27.39 & 39.94 & 47.30 \\
\hline Building, contracting, etc & 16.50 & 21.75 & 30.17 & 61.17 & 26.97 & 35.56 & 49.32 & 46.80 \\
\hline Miscellaneous manufacturing & 16.25 & 25.08 & 30.08 & 64.92 & 25.03 & 38.63 & 46.33 & 47.20 \\
\hline Transport and storage & 16.58 & 25.25 & 32.33 & 69.08 & 24.00 & 36.55 & 46.80 & 47.90 \\
\hline Public utility services & 15.42 & 25.67 & 28.17 & 57.83 & 26.66 & 44.39 & 48.71 & 47.30 \\
\hline Government industrial establishments & 19.25 & 29.92 & 38.83 & 69.75 & 27.60 & 42.90 & 55.67 & 47.30 \\
\hline Average of above sectors & 16.35 & 22.89 & 31.29 & 64.50 & 25.35 & 35.49 & 48.51 & 47.16 \\
\hline
\end{tabular}

Note: "Girls" refers to females under eighteen, "boys" to males under twenty-one years of age.

Source: Ministry of Labour, "Average Hours and Earnings Enquiry”, October 1935, Ministry of Labour Gazette, February-July 1938. 
part of their status as being different from and senior to schoolchildren rested upon this responsibility.

The negotiation between juveniles' status as independent wage-earners and the needs of the family economy was achieved by reciprocal relationships between wage-earning children and their parents. The practice of workers "tipping up" their earnings to the family economy was widespread. Young workers would hand over their wage packet unopened to their mothers, and receive a proportion of it back as "spending money", the remainder going to the family economy. ${ }^{36}$ Both boys and girls were expected to contribute the majority of their earnings to the household economy. Mr Savage was born in about I 906 and grew up in Ordsall, a working-class district of Manchester. He had an older brother and sister, both already at work when he left school, and his father was a skilled factory worker. Mr Savage began work at the age of twelve in a local barber's shop, washing customers' hair. He vividly remembered his first wage: "two shillings threepence per week. That was two shillings wages and threepence for myself. I used to rush home on Saturday night and the old lady [his mother] was waiting, cause it was needed in those days, two bob." 37

Contemporary surveys corroborate Mr Savage's memory that he had to give up the majority of his wage to his parents. Interwar social surveys suggest that most juveniles contributed between 70 and 95 per cent of their earnings to the family economy until the age of eighteen, after which the proportion contributed dropped to between 20 and 50 per cent. ${ }^{8}{ }^{8}$ Being a juvenile, then, was a period when financial independence was gradually extended; there were distinct social, as well as economic differences between the lifestyles of the youngest workers and those single men and women in their late teens who were, in Andrew Davies's words, "relatively privileged consumers of leisure". 39

\section{GENDER, AGE, AND EMPLOYMENT PATTERNS}

For employers, the main attraction of juvenile workers was their cheapness. As Moehling has pointed out, the wages offered to married women

36. Rowntree, Poverty and Progress, p. 27; Davies, Leisure, Gender, Poverty, p. 91; Langhamer, Women's Leisure, pp. IOI-IO2.

37. TLSL, Manchester Studies collection, tape no. 477, interview with Mr Savage.

38. J.L. Harley, "Report of an Enquiry into the Occupations, Further Education and Leisure Interests of a Number of Girl Wage-Earners from Elementary and Central Schools in the Manchester District, with Special Reference to the Influence of School Training on their use of Leisure" (M.Ed., Manchester, 1937), pp. 56-57; Rowntree, Poverty and Progress, pp. 27, 78 -8 I, 83-95, I 27-I 42; Mass Observation Archive, University of Sussex [hereafter, MOA], Worktown Collection, Box 28/B, Household Budgets, ms: untitled budget of family of six, n.d., c.1938, and ms: untitled family budget, ms, 9 May 1938; Langhamer, Women's Leisure, pp. 100-103.

39. Davies, Leisure, Gender, Poverty, p. 8 I. 
had to be relatively high to compensate for the loss of their domestic labour in the home. ${ }^{40}$ As Table I indicates, juveniles accepted lower wages. Maintaining young people's position as dependants in the family home was thus in the interests of many employers, and was a major reason why many firms imposed a marriage bar following World War I, thus maintaining a youthful, and therefore cheap, labour force. ${ }^{4}$ It was not until after World War II that labour demand rose sufficiently, and parttime work became more accepted by both workers and employers, for the marriage bar to disappear.

This situation affected the kinds of work that juveniles undertook. Insecure, low-paid jobs dominated the juvenile labour market, particularly for boys. Over 30 per cent of boys aged between fourteen and sixteen years of age were employed as messenger boys, delivery lads, or similar at both interwar censuses. ${ }^{42}$ Girls were more likely to enter low-skilled factory work, which employed over 40 per cent of them, or domestic service, their single largest employer, which occupied employed 30 per cent of girls in I92 I and I93 I. ${ }^{43}$ This gender division was the consequence of the sexual division of labour in the adult labour market, and the effects of this on juveniles' limited choices. Most apprenticeships for skilled trades were restricted to boys, aged fifteen or sixteen. These were poorly paid, but had traditionally led to skilled adult employment. Consequently, employers who wanted unskilled and casual workers frequently sought boys aged below sixteen, who were marking time before trying to get an apprenticeship or skilled factory work. Girls, who were expected to give up their fulltime employment on marriage, were consequently in demand for light manufacturing manual work, or junior clerical positions which did not demand lengthy training; both sectors were expanding in the interwar years and offered secure work by the late i930s.44

This was the case in Dagenham. The town, which expanded through the interwar years due to high labour demand from manufacturers situated in greater London, had the lowest rate of adult female participation rate recorded in the dataset used in the Appendix - I 2 per cent - but 8 I per cent of girls were in the labour force, far above than the national average, and a high 92 per cent of boys. Local labour demand was partly

40. C. Moehling, "Women's Work and Men's Unemployment", Journal of Economic History, 6I (200I), pp. 928-929; E. Roberts, A Woman's Place: An Oral History of Working-Class Women I890-I9I4 (Oxford, I984), pp. I59-I6I.

4I. P. Scott, "Women, Other 'Fresh' Workers and the New Manufacturing Workforce of Interwar Britain", International Review of Social History, 45 (2000) p. 462; J. Childs, "Quaker Employers and Industrial Relations", Sociological Review, I2 (1964), pp. 298-300.

42. Census of England and Wales, I92 I: Occupation Tables, Table 3 (London, 1924); Census of England and Wales, 193 I: Occupation Tables, Table 4 (London, I934).

43. Census of England and Wales, I92 I: Occupation Tables, Table 4 (London, I924); Census of England and Wales, 1931: Occupation Tables, Table 3 (London, 1934).

44. For an extension of this discussion see Todd, Young Women, Work, and Family, pp. 46-52. 
responsible. Households headed by the is per cent of adult men employed as unskilled workers, often in seasonal or insecure work, had good reason to welcome supplementary earnings. Boys could easily obtain "blindalley" but relatively well-paid work: i 8 per cent were employed as messengers, and is per cent as unskilled workers in I93 I. The insecurity of such employment made girls' earnings valuable, and they were in demand for work in the expanding textile goods trade ( 16 per cent), but also in nonmanual sectors: I 2 per cent were employed as shop assistants, I 3 per cent as clerks, many of them travelling to nearby, middle-class areas like Ilford, where demand for girl labour outstripped the limited local supply. ${ }^{45}$ The small proportion of adult women who were employed were mostly parttime charwomen or cleaners. Such work fitted around family commitments, important since the area had a large dependency ratio (the number of dependent children under fourteen years of age to the number of adults).

Table I demonstrates that juveniles' earning potential was far more limited than that of adult men or women. However, juveniles could provide a more reliable source of income than adults due to their lower likelihood of being unemployed. Unemployment peaked at 7 per cent for sixteen- and seventeen-year-old girls in I93 I and 8.3 per cent for boys in I932, while adult unemployment in 1932 stood at I4 per cent for adult women and 25 per cent for adult men. ${ }^{6}$ As Beveridge suggests, this actually demonstrated that juveniles were less vulnerable to long-term unemployment; many of them did experience short-term unemployment between jobs, but there was a rapid turnover within the juvenile unemployed. ${ }^{47}$ These characteristics: short-term unemployment, casual or insecure work, an insignificant gender differential in earnings, and a significant differential between juvenile and adult earnings were crucial in shaping the life-stage between school and marriage.

\section{WAGE-EARNER OR SCHOLAR: CLASS, GENDER, AND LIFE CHANCES}

Before the implementation of the 1944 Education Act in 1947, access to secondary education was determined by ability to pay fees or to win one of a small number of scholarships between the ages of eleven and thirteen. The highest levels of educational participation were recorded in those areas where a large proportion of men were employed in non-manual occupations, such as Hornsey, where 54 per cent of men were employed in

45. T. Young, Becontree and Dagenham (Becontree, 1936), p. I 22.

46. W.R. Garside, "Juvenile Unemployment and Public Policy between the Wars", Economic History Review, 30 (1977), p. 377; M. Thomas, "Labour Market Structure and the Nature of Unemployment in Interwar Britain", in B. Eichengreen and T.J. Hatton (eds), Interwar Unemployment in International Perspective (London, I988), p. I 16.

47. W.H. Beveridge, Unemployment: A Problem of Industry, 2nd edn (London, I930), p. 406. 
non-manual occupations, and 22 per cent of girls and 25 per cent of boys were in education, when the national average stood at ro per cent and I I per cent respectively.

Gender was influential, as well as class, in shaping access to extended education. Social historians of interwar England have identified gender bias towards young men in the allocation of financial and social independence ${ }^{48}$ and education, ${ }^{49}$ and while this has often been ascribed to culturally defined gendered roles, it may in fact point to the continuing influence of a juvenile's earning potential over the allocation of scarce resources. Personal testimonies suggest that many parents considered education a more worthwhile investment for boys than girls, due to males' general expectancy of a longer working life. Dolly's father, a plumber, "believed the lads should go to High School. I passed a scholarship to go, but wasn't allowed to. We were short of money, and he considered that lads would need the education more than a girl. I felt badly about that at the time." 50 The increasing degree of vertical, gendered occupational segregation, which meant that boys were more likely to be able to obtain managerial-level jobs which relied on extended education, gave support to this view. ${ }^{\text {II }}$

Family position also affected a juvenile's likelihood of entering the labour force. The strength of the relationship between the dependency ratio and girls' labour force participation, demonstrated in the Appendix, highlights this. Social surveys and subsequent historical studies indicate that younger siblings in large families were able to benefit from the economic contribution being made by older, wage-earning brothers and sisters. ${ }^{2}$ Mrs Savage, who entered industrial employment in Manchester during the early i920s, as the oldest of five, recalled that her wage was necessary "bread for the kids. Because I was the oldest girl." 33 In contrast, Rose Gamble was able to take up a scholarship to secondary school in I930s London due to the earnings of her two older sisters. ${ }^{54}$ The effect of gender on young people's lives was thus partially determined by family composition, household income, and local labour demand.

48. Davies, Leisure, Gender, Poverty, pp. 85-86; Langhamer, Women's Leisure, p. Iо2.

49. S. Alexander, "Becoming a Woman in London in the I 920 and 1930 ", in idem, Becoming a Woman (London, I994), p. 2 I3; D. Beddoe, Back to Home and Duty: Women Between the Wars (London, 1988), p. 41; J. Kamm, Hope Deferred: Girls' Education in English History (London, I 965$)$, p. 233.

50. Lifetimes History Group, Something in Common, p. I3.

5 I. D. Vincent, "Mobility, Bureaucracy and Careers in Early-Twentieth-Century Britain", in A. Miles and D. Vincent, Building European Society: Occupational Change and Social Mobility in Europe, 1840-1940 (Manchester, 1993), p. 221.

52. Davies, Leisure Gender, Poverty, p. 98; J. Smyth, "'Ye Never Got a Spell to Think Aboot It': Young Women and Employment in the Inter-War Period: A Case Study of a Textile Village", in E. Gordon and E. Breitenbach (eds), The World is Ill Divided: Women's Work in Scotland in the Nineteenth and Early Twentieth Centuries (Edinburgh, 1990), p. 107.

53. TLSL, Manchester Studies Collection, interview no. 477, interview with Mrs Savage.

54. R. Gamble, Chelsea Child (London, I974), p. I 20. 
However, it is equally clear that most working-class juveniles, both girls and boys, had no opportunity to enter secondary education. The negative relationship between the juvenile ratio (the ratio of the number of juveniles to the number of adults) and adult women's labour-force participation, highlighted in Table 4, indicates that the household member most likely to be maintained outside the labour force if sufficient income could be earned by resident workers was the wife and mother, due to her domestic responsibilities. Poverty, and vulnerability to it, was thus a far more overwhelming constraint on most juveniles' choices than gender. This was something that struck Jim Wolveridge when he left school in London at the age of fourteen in I934. He was "looking forward to what I thought would be freedom, and having a job and money in my pocket", 5 but in the end

I went into a dead end job [...]. Not many of the kids in the neighbourhood did get good jobs [...]. I spent a few weeks calling in at the juvenile exchange at Toynbee Hall, but the few vacancies that were available were for boys who'd had secondary or grammar school education. This left me, and a good many more like me, out in the cold. ${ }^{6}$

It is significant that Wolveridge, and others like him, do not seek to construct their self-representation within the discourse of the "economically worthless but emotionally 'priceless' child" that prevailed in the pleas of social investigators and educationalists for greater social and cultural opportunities for working-class juveniles. ${ }^{57}$ Rather, they attempt to make sense of their exploitation as workers, emphasizing their similarity with and connections to adult workers. Cultural historians suggest that there is no legitimate reason why people should be expected to view their life experience through the prism of class, ${ }^{8}$ but the experience and memory of being a juvenile worker in interwar England suggests otherwise. Remembering work and wage-earning in this manner clearly made logical sense to many men and women, and was certainly less traumatic than the alternative at which many of their narratives hint, in which parental failure was given as the reason why their children had to enter low-paid work. The framework of class thus helped many young people to make sense of their lives as sons or daughters in their parents' houses, in a way that strengthened rather than threatened the affective and economic bonds of family life.

55. J. Wolveridge, Ain't It Grand, or, This Was Stepney (London, 1976), p. 56.

56. Ibid., p. 57.

57. P. Cox, Gender, Justice and Welfare: Bad Girls in Britain, 1900-1950 (Basingstoke, 2003), p. I 26.

58. P. Joyce, "The End of Social History?", Social History 20 (1995), pp. 73-9I; J. Vernon, "Who's Afraid of the 'Linguistic Turn?' The Politics of Social History and its Discontents", Social History, i9 (1994), pp. 8I-97. 


\section{UNEMPLOYMENT, THE MEANS TEST, AND REDEFINING YOUTH}

The period between I 900 and I939 saw children and, to a lesser extent, juveniles, brought under greater state supervision and protection. Osgerby and Cox have suggested that this state intervention was shaped by the desire of successive governments, social investigators, and educationalists to protect, yet also police, young people. ${ }^{99}$ This clearly had psychological and cultural motivations, as both Hendrick and Cox have shown. ${ }^{60}$ However, Neary has compellingly argued that the state's construction of young people as socially distinct from adults helped to create a social category - "youth - which cut across income groups and implied a challenge to class-based interests". ${ }^{61}$

This was also shaped by economic development. The demand for "blind-alley" work was diminishing by the mid-I930s, while demand in light manufacturing and clerical work, which had more interest in employing young people with some secondary education, grew. Moreover, juvenile unemployment in the early 1930s, while lower than adult unemployment, could be addressed by using the existing discursive construction of juveniles as dependants within the family to justify their limited entitlement to unemployment benefit and increasing institutionalization in "dole schools" or mainstream education. ${ }^{62}$ In 1935, Political and Economic Planning (PEP) recommended the raising of the school leaving age to fifteen to meet the needs of a labour market that required educated labour, and in which demand for younger juveniles was reducing. ${ }^{63}$ The raising of the school leaving age was subsequently agreed in law, although its implementation was postponed until 1947 due to World War II.

It would, however, be inaccurate to imply that changes in the treatment and definition of young people were prompted solely by high political and economic motivations. Changes in working-class responses to the state's treatment of juveniles were also crucial. We still know too little about the relationship of working-class people to state and charitable welfare initiatives in the twentieth century. Many social histories have suggested that the relationship was characterized by antagonism and suspicion, with working-class communities opposing the institutionalization of children,

59. Osgerby, Youth in Britain, pp. I37-138; Cox, Gender, Justice and Welfare, ch. 4.

60. Ibid., ch. 6; H. Hendrick, Images of Youth: Age, Class, and the Male Youth Problem I8801920 (Oxford, I990), ch. 4.

61. M. Neary, Youth, Training and the Training State: The Real History of Youth Training in the Twentieth Century (Basingstoke, I997).

62. See S. Todd, "Young Women's Employment and the Family" (D.Phil, University of Sussex, 2003), pp. 229-235.

63. Political and Economic Planning, The Entrance to Industry (London, 1935). 
for example. ${ }^{64}$ Against this, recent studies have highlighted a more complex relationship. Davies's work on criminal gangs has demonstrated that working-class adults opposed certain forms of police intervention in their communities, but also drew upon their authority when the boundaries of acceptable behaviour were considered to be breached. ${ }^{65}$ Cox's cultural history of the policing of girls demonstrates that parents did not uniformly impose the taking of their children into protective or custodial care. ${ }^{66}$

Reactions to high unemployment in the early I930s and the National Government's treatment of this crisis shed more light on the relationship between the working class and the state. This subject indicates why working-class suspicion of state welfare provision remained in the postwar years, but also how this was combined with a continued desire to engage with and use the state. The economic crisis brought the paradox of juvenile wage-earners - treated and paid as dependents, but in fact often crucial to the family economy - forcefully into the limelight. As juveniles' earnings were a crucial component of most working-class family budgets, it would not be expected that adult male unemployment would positively affect their labour force participation. This is supported by the regression analysis offered in the Appendix. However, it is difficult to test for the effects of unemployment with county-level data.

Table 3, model 2, suggests that adult male unemployment may have affected boys' labour force participation positively. ${ }^{67}$ This reflects the results of gendered occupational segregation, apparently supporting Eichengreen's conclusion that family income exerted a more significant effect upon boys' labour force participation than girls' ${ }^{68}$ The insignificance of adult male unemployment for female labour force participation points to the concentration of male unemployment in labour markets offering limited employment opportunities to girls and women. Households in such areas might rely on a married woman's casual employment which may not have been enumerated on the census; daughters' employment away from home as residential domestic servants (which may have led to them being undercounted by the county tables if they were recorded at an employer's household in a different county); and on sons' regular

64. A. Davin, Growing Up Poor: Home, School and Street in London I870-1914 (London, 1996); Hendrick, Images of Youth.

65. A. Davies, "Glasgow's Reign of Terror: Street Gangs, Racketeering and Intimidation in the I 920 s and I930s", Contemporary British History (forthcoming).

66. Cox, Gender, Justice and Welfare, pp. I26-i 27.

67. Although the result is not statistically significant, it points to a possible trend, that may be disguised by the fact that the data is available only at the level of the county, not the household. 68. B. Eichengreen, "Juvenile Unemployment in Twentieth-Century Britain: The Emergence of a Problem”, Social Research, 54 (1987), p. 288. 
earnings. Consequently, boys became major breadwinners in many working-class families.

Paternal unemployment also had profound social and psychological consequences. Surveys of unemployed households during the r930s showed that paternal unemployment increased the financial responsibilities and anxieties experienced by young workers, particularly among sons. ${ }^{69}$ Mr. Savage's childhood was affected by his father's unemployment following World War I, which led him to undertake casual jobs throughout his schooldays. When he left school he and his oldest sister became the family's only breadwinners: "my sister worked in the mill [...] so there was only my wages, my few bob, and her few bob was keeping the lot"..$^{70}$ In north-west England, where a daughter could gain relatively well-paid work in the textile industry, pressure on her was likely to be as intense as on any son. The positive effect of male employment in the textile industry on girls' labour force participation, indicated in Table 2, model 2, highlights this.

The introduction of the household means test in I93 I intensified the pressure on wage-earning children. It forced reliance on supplementary earners when a household head was unemployed, since the test assessed individuals' entitlement to unemployment benefit in the context of all household earnings. In the depressed mining town of Stanley, in I924, only Is per cent of households living in poverty were in such straits because of the unemployment of the chief wage-earner, despite a heavy reliance on male breadwinners. ${ }^{71}$ Yet in relatively affluent York in 1936 , almost 30 per cent of poverty was attributable to adult male unemployment, ${ }^{72}$ and a similar proportion in Bristol in $1938 .{ }^{73}$ Successive investigations from I93 I onwards found that most unemployed men were chiefly supported by other relatives, with sons and daughters being of greatest importance, in that order. ${ }^{74}$

This had powerful social and emotional consequences for family relationships. The Carnegie Trust found evidence that wage-earning sons, particularly those in their late teens and twenties, were forced to lodge

69. P. Ayers, "The Hidden Economy of Dockland Families: Liverpool in the I930s", in P. Hudson and W.R. Lee (eds), Women's Work and the Family Economy in Historical Perspective (Manchester, I990), pp. 271-290; Pilgrim Trust, Men Without Work (Cambridge, 1938), p. 91; Moehling, "Women's Work", pp. 928-929.

70. TLSL, Manchester Studies Collection, 477, Mr Savage.

71. Bowley and Hogg, Has Poverty Diminished?, p. 197.

72. Rowntree, Poverty and Progress, p. $5 \mathrm{I}$.

73. Tout, Standard of Living in Bristol, p. 46.

74. C. Cameron, A. Lush, and G. Meara, Disinherited Youth: A Report on the I $8+$ Age Group Enquiry Prepared for the Trustees of the Carnegie United Kingdom Trust (Edinburgh, 1943), pp. 70, 75; Rowntree, Poverty and Progress, pp. I88-189; H.L. Beales and R.S. Lambert (eds), Memoirs of the Unemployed (London, I934), pp. 20, 40-4I, 82-87; Pilgrim Trust, Men Without Work, pp. I47-148. 


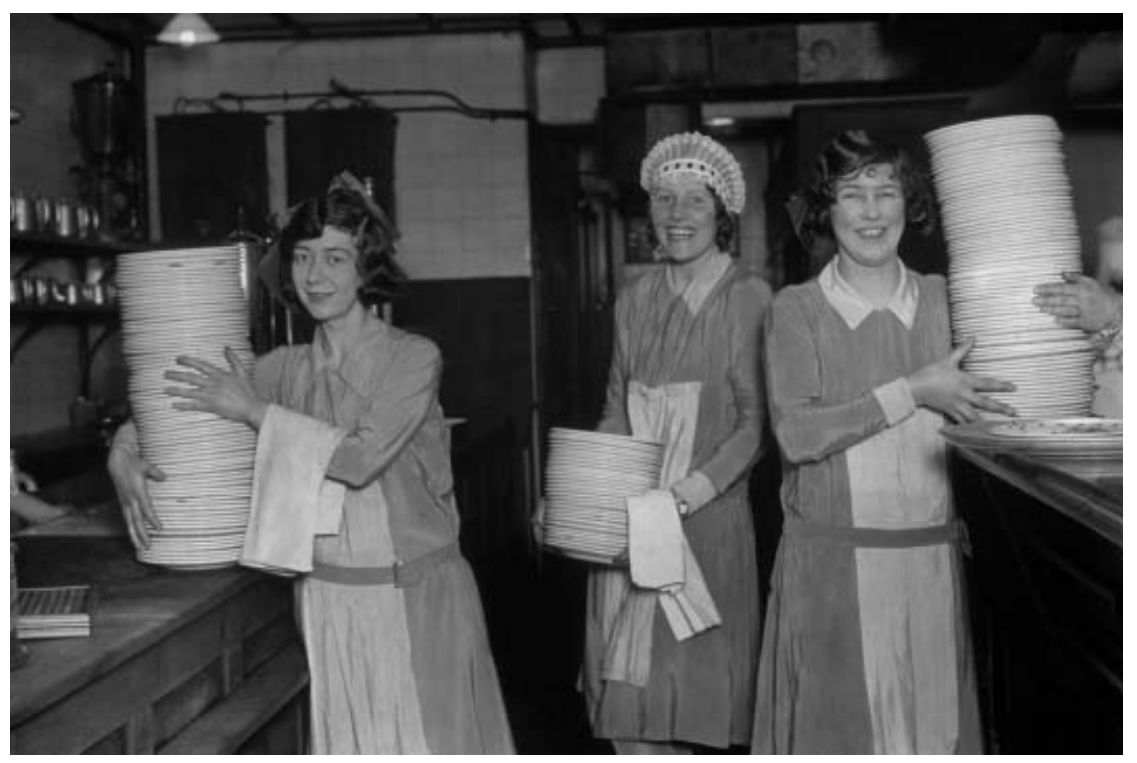

Figure 2. "Ready for Breakfast". By the I930s, becoming a waitress was an increasingly realizable aspiration for young working-class women, keen to take advantage of the employment opportunities - and the social life - available in big cities like London and Manchester. The arduous work and poor wages were compensated for by the working hours, which left evenings free for leisure.

Photograph by E.H. Corcoran. Hulton Archive, Getty Images. Used with permission.

away from the parental home, while continuing to contribute to the household's economy, in order to avoid the household losing income from either earnings or unemployment benefit. The Trust noted that the income of most of these households enabled them to live at or below subsistence level; no wage-earning sons or daughters investigated were supporting an affluent lifestyle..$^{75}$ Stanley Iveson grew up in Nelson, a Lancashire textile town which suffered high unemployment, particularly in the early i930s. A mill worker, he remembered the effect of the means test on the people in his street:

[...] in I93 I when people were being knocked off the dole, there was a big building across [the street] [...] it was a model lodging house. And people used to - lads used to go and sleep there, during the week [...]. It was a shilling a night. So they was able to draw the dole. But they went home for their meals. And it broke homes up in those days. ${ }^{76}$

These findings extend Hatton and Bailey's conclusion that there were no economic incentives to leave the workforce and live off benefit in the

75. Cameron et al., Disinherited Youth, p. 75 .

76. TLSL, Manchester Studies Collection, tape no. 898, interview with Stanley Iveson. 
interwar years. ${ }^{77}$ Juveniles' low unemployment rates do not mean that they were unaffected by the effects of high unemployment. Sons in particular found that the means test intensified pressure on them. This situation reinforced gender roles, since pressure fell most heavily on male wage-earners, but it disrupted established age-specific roles. It was also profoundly symbolic, as an economic crisis that was addressed by a form of state intervention which criminalized the survival strategies operated by a wide range of families, not simply the very poor. Even more significantly, "it broke up homes" - rupturing the family, the maintenance of which had hitherto appeared to be a shared interest between the state and the working class.

This had a long-term impact on the treatment and representation of juveniles. Juvenile unemployment accelerated the move towards institutionalizing juveniles in schools and training programmes. With the 1927 Unemployment Act, the government reformed juvenile unemployment centres, established in I9I9, into juvenile instruction centres - "dole schools", designed to provide "more intelligent and more adaptable recruits". ${ }^{8}$ Benefit entitlement was made contingent on attendance. The type of general education that these centres offered - "not $[\ldots]$ training for specific occupations, but [...] mainly practical in character"79 - reflected the vocational role that the Butler Education Act of 1944 allotted to secondary modern schools, which educated the majority of English young people between the late i940s and the early i970s.

However, the consequences of adult male unemployment and the means test were even more significant. Paternal unemployment led this generation to question juveniles' role as wage-earners and became an integral part of the popular memory of the "hungry thirties"; recalled in the Labour Party's election slogan of 1945: "Ask Your Dad". This is apparent in the life histories of those who grew up in the I950s and I960s; comparison with the interwar years is central to their representation of those decades as relatively affluent. For example, Alice Crumpsall, born in Lancashire in 1930, recalled her father's entry to employment, ten years before her birth:

[...] his father couldn't afford the clothes, you see, that he wanted, he wanted to go into office work so he had to end up as a labourer. And that was through his father you see [...]. I always think that it's the background, you know, if you don't get the proper background you haven't a chance. ${ }^{80}$

77. Hatton and Bailey, "Unemployment Incidence", pp. 646-648.

78. Ministry of Labour, Report of the Committee on Education and Industry (England and Wales), Second Part, (Malcolm Committee) (London, 1928), p. 27.

79. National Advisory Council for Juvenile Employment, First Report (London, 1929), p. 4.

80. North West Sound Archive (hereafter NWSA), 2000.0548, audio-cassette recording, interview with BA (pseudonym: Alice Crumpsall). 
During and after World War II, the government increasingly attempted to make the life-stage between leaving school and reaching eighteen years of age one that should be made distinct from adulthood. World War II led to increasing scrutiny of "youth" provision. The Youth Service catered for the recreational and welfare needs of young people aged between fourteen andeighteen, the age at which conscription began. ${ }^{8 \mathrm{I}}$ Provision for young people increasingly became the responsibility of the Ministry of Education rather than the Ministry of Labour and National Service.

A report on The Youth Service After the War was commissioned by the President of the Board of Education in 1942; it recommended that youth employment be dealt with alongside leisure provision and "training for citizenship". Attention was paid to individual fulfilment but also to "the needs of the community". These were to be met through matching labour demand to the supply of young, unskilled workers; encouraging employers and young workers to support educational initiatives; and ensuring that earnings were limited because "A boy who, within a year [...] of leaving school, is earning $£_{3}$ or $£_{4}$ a week may quickly acquire a certain standard of living" which could be insecure or indulgent. The postwar Youth Employment Service that was established in 1948 was thus "both an educational and an employment Service", coordinated by Local Education Authorities. It was intentionally comprehensive, rather than addressed only to those unable to find work through other means as had been the case before the War. ${ }^{82}$

The Labour government of 1945 implemented these wartime recommendations, raised the school leaving age to fifteen in 1948, and also developed the wartime proposal that government should seek to make the youth labour market more secure. Significantly, Labour chose to do this not through direct intervention into recruitment and retention practices, but through government subsidy of vocational training, via support for apprenticeships, and through the Family Allowances Act of 1945, which incorporated financial assistance to support dependants over fourteen but under twenty who were in full-time education or "full-time [vocational] training [...] and not in receipt of earnings which provide for a livelihood", a definition meant to include apprentices. ${ }^{83}$ This approach provided support which had been lacking in the preceding decades, and greatly expanded the amount of training open to young workers. However, it also strengthened and legitimated young people's position as low-paid work-

81. Ministry of Education, The Purpose and Content of the Youth Service (London, 1943).

82. Ministry of Labour, The Juvenile Employment Service (London, 1948), p. 2; Ministry of Labour, Report of the National Youth Employment Council on the work of the Youth Employment Service 1947-1950 (London, 1950), p. 9.

83. TNA, LAB 19/213, Home Affairs Committee, typed ms: "Family Allowances for Apprentices - A Possible Economy", c.1960. 
ers, by representing them as dependents on the family and state and as trainees, as distinct from "normal" workers.

The emphasis placed on vocational guidance was similar. The Ministry of Labour's Young Worker - a blueprint for the postwar Youth Employment Service (YES) -claimed that "it may not always be the best or the most progressive jobs which will carry the highest wages [...] [consequently] experienced guidance will be very necessary". ${ }^{84}$ But in emphasizing guidance for choice, the initially well-funded YES suggested that, ultimately, the existence of insecure employment could be at least partially ascribed to poor choices by working-class parents and their children. The approach of postwar legislation, then, embodied acceptance of the existence of unskilled work and a pool of unskilled workers. An attempt was made to redefine such employment as entry-level work, thus making the adult labour market more secure, and unskilled work a stepping stone to better jobs. State support helped to develop training and financial support within this context. However, the approach ensured that young people remained a crucial element of the pool of unskilled labour, and glossed over the fact that, as we shall see below, many working-class families continued to rely on the low and sometimes insecure earnings of sons and daughters.

Young people continued to be an important source of labour. In I95 I, 75 per cent of young women aged between fifteen and nineteen and 84 per cent of young men of the same age were in full-time employment. ${ }^{85}$ Their wages had risen, and age-specific wage differentials fell between the late I930s and mid-1950s. In 1938 young men aged between fourteen and twenty years who were employed in industry or public service earned an average $6 \mathrm{~d}$ per hour - 39 per cent of adult males' average hourly earnings. By I955 their hourly earnings averaged 2s id per hour, 46 per cent of adult males' average hourly earnings. Over the same period girls aged between fourteen and eighteen years saw their average hourly earnings rise from $3 \mathrm{~d}$ per hour to is $7 \mathrm{~d}$ per hour. ${ }^{86}$ Young wage-earners also enjoyed a greater amount of spending money by the early I950s - about I Is $4 \mathrm{~d}$ per week on average, according to a study of Birmingham's working-class youth. ${ }^{87}$

Ultimately, though, young people's continued, conspicuous presence in the labour market is explained by their contribution to the working-class family's standard of living. Youthful wage-earning actively contributed to working-class affluence - thus demonstrating its limitations. This pattern had become evident in the late I930s. In interwar Dagenham, the low male unemployment rate and the large proportion of men employed in

84. Ministry of Labour, The Young Worker (London, I944), p.II.

85. Census of England and Wales, 1951: Occupation Tables (London, 1954), table 3.

86. Todd, Young Women, Work, and Family, p. 33; "Average Weekly Earnings in the Last PayWeek of October 1955", and "Average Hours worked in the Last Pay-Week of October I955", Ministry of Labour Gazette (March 1956), p. 82.

87. B.H. Reed et al., Eighty Thousand Adolescents (London, I950), p. 38. 
transport and communication ( 28 per cent) and in metals ( 9 per cent), both sectors paying above average wages in I93 I, indicate that high juvenile labour force participation was not based solely on economic need. This remained the case after World War II. Hopkins suggests that in I954 38 per cent of households had two wage-earners and a further i 9 per cent housed three or more wage-earners. ${ }^{88}$ Ferdynand Zweig's study of working-class families highlighted that multiple contributions to the family economy were essential to the achievement of (limited) affluence. In most households headed by manual workers, the purchase of such signifiers of affluence as domestic appliances or television sets could only be afforded if overtime pay or the earnings of "supplementary" earners - wives, sons or daughters - were accumulated. ${ }^{89}$

In the I950s, demand for married women as part-time workers rose, and was aided by the determination of many working-class parents to help their children to attain a better future. Wilmott and Young's study of East London in the early i950s found that married women went out to work to pay for children's school supplies..$^{\circ}$ But women did not replace young people as supplementary wage-earners. In 1950, a study of I,400 young working-class men found that those who had been out at work for more than a year were less likely to have mothers out at work than recent school-leavers. ${ }^{9 \mathrm{I}}$ This points to the continued importance of young people as wage-earners. A mother's domestic responsibilities meant that the presence of another wage-earner in the household was to be welcomed. The financial importance of young wage-earners is demonstrated by their continued contribution of the majority of their earnings to the family economy..$^{2}$

This pattern should not be viewed as a hangover of an older custom, or as an attempt to increase luxury consumption at the expense of a child's educational or training opportunities. "Affluence" remained limited and insecure for working-class households in the I950s, with most continuing to experience periods of financial insecurity. Hatton and Bailey's reanalysis of Rowntree's 1950 poverty survey convincingly suggests that I I. 8 per cent of working-class households lived in poverty- 7.I per cent of all households in England. ${ }^{3}$ The single greatest cause of poverty,

88. H. Hopkins, The New Look: A Social History of the Forties and Fifties in Britain (London, 1963), pp. 3 I $2 \mathrm{ff}$.

89. F. Zweig, The British Worker (Harmondsworth, I952), p. 66.

90. T. Young and P. Willmott, Family and Kinship in East London (London, 1957), p. 177-179.

91. L. Wilkins, The Adolescent in Britain (London, 1950), p. 8.

92. R.F.L. Logan and E.M. Goldberg, "Rising Eighteen in a London Surburb: A Study of Some Aspects of the Life and Health of Young Men", British Journal of Sociology, 4 (1953), pp. 323345 .

93. R.E. Bailey and T. Hatton, "Seebohm Rowntree and the Postwar Poverty Puzzle", Economic History Review, 53:3 (2000), pp. 517-543. 
according to Rowntree, was old age, but paternal sickness or absence was second and large family size third. ${ }^{94}$

Moreover, the development of working-class commercial consumption was slow in the subsequent decade. Rationing of various foodstuffs remained in force until I954. In that year, less than io per cent of English households owned washing machines and less than 20 per cent possessed a television set. Television remained beyond most working-class pockets until the early 1960s; washing machines and refrigerators achieved mass ownership a decade or more later. ${ }^{95}$ While Mark Abrams justifiably identified the teenager as a particularly affluent member of the working class in 1959 - and teenage consumption as "an almost exclusively working-class phenomenon" - his data on their purchases of records, clothes, films, and dances were selective and, as Abrams himself suggested, highlighted a change from the first half of the decade. ${ }^{6}$ Successive studies suggested that in the early i950s young wage-earners' leisure was occupied with family activities, visiting friends, and attending the cinema once or twice weekly 97 - not very different from the situation in the late I930s, as Langhamer has pointed out..$^{8}$

This is not to suggest that the early postwar years were not socially and economically distinct from the late I930s. The earnings and spending data presented above highlight that this is not so. This case is also made convincingly by existing studies of youth, education, and family life in the 1950s. 99 These indicate that the changes in employment patterns and the family economy which appear subtle here - the substitution of married women's work for that of sons and daughters of fourteen, fifteen, sixteen, for example - were bound up in dreams and desires. The memory of limited opportunity in the interwar years meant that working-class parents, as well as the state, were active in changing youthful lifestyles after World War II. Postwar educational reform, particularly the introduction of free, universal secondary education, was popular. Many parents prioritized children's education and leisure in the I950s, as Wilmott and Young's findings suggest. ${ }^{100}$

94. Rowntree and Lavers, Poverty and the Welfare State, pp. 34-35.

95. S. Bowden and A. Offer, "Household Appliances and the Use of Time", Economic History Review, 47 (1994), pp. 745-746.

96. M. Abrams, Teenage Consumer Spending in 1959 (London, 196I), p. 8.

97. Reed et al., Eighty Thousand Adolescents, p. 52; Wilkins, The Adolescent in Britain, pp. 80IOI.

98. Langhamer, Women's Leisure, pp. 97-102. See also Davies, Leisure, Gender, Poverty, pp. 96-100.

99. See for example C. Steedman, Landscape for a Good Woman (London, I986); B. Osgerby, "From the Roaring Twenties to the Swinging Sixties: Continuity and Change in British Youth Culture, I929-59", in B. Brivati and H. Jones, What Difference Did the War Make? (Leicester, I993), pp.8I-85.

ı00. Young and Willmott, Family and Kinship, p. 177-179. 
Brian Green was born in Bolton, Lancashire in I94I. His father was a miner and "When I was a lad, he took me to the top of the pit, and he said, erm, 'you've two things now, you get educated, or else you go down this place', and [...] so I thought, it's education for me!” Brian Green failed the examinaton governing entry to selective secondary schools, but he attended a technical college, with his parents' support, after leaving school at fifteen. ${ }^{\text {IOI }}$ As Valerie Walkerdine has pointed out, this was promoted and strengthened by the postwar state's meritocratic discourse, which promised "the bright future of the new housing estates where, by our abilities and aptitudes we would be chosen to take our place in the land of opportunity". ${ }^{102}$ Walkerdine's father was a skilled manual worker who wanted his daughter to become a doctor. ${ }^{103}$ Universal secondary education, rising affluence, and demand for married women's work, combined with great determination on the part of many parents to expand their children's opportunities, were crucial in changing patterns of employment and family budgeting in the I950s and I960s. Yet as the partial substitution of young wage-earners by married women suggests, the strategy for doing so remained engaging with a labour market which demanded a pool of low-paid labour. A single male manual worker's wage was frequently insufficient to pay for the better life parents wanted for their children.

This offers a different reading of the mid-twentieth century than those currently on offer in the historiography. Langhamer and Osgerby rightly stress a degree of continuity in youthful leisure activities and family relations between the I930s and the I950s. But their insightful researches also discern differences between the pre- and postwar periods, in the amount of spending money young people possessed, the independence they asserted, the leisure time they enjoyed. This is attributed to postwar affluence. ${ }^{104}$ Yet, we have seen that affluence was very limited for most working-class families in the early i950s.

The years between I945 and I955 were significantly different, socially and economically, from the late i950s and early i 960 . While this has been emphasized by economic histories, ${ }^{\text {Ios }}$ social and cultural historians have frequently considered "the postwar period" between the late I940s and early 1960 s as a coherent whole. ${ }^{106}$ In fact changes in employment

IоI. NWSA, 2000.034I, audio-cassette recording, interview with IW (pseudonym: Brian Green).

I02. V. Walkerdine, "Dreams from an Ordinary Childhood", in L. Heron (ed.), Truth, Dare or Promise: Girls Growing Up in the Fifties (London, 1985), p. 75.

I03. Ibid., p. 68.

104. Langhamer, Women's Leisure, pp. 97, 99, ro2; Osgerby, "Roaring Twenties", pp. 8 1, 87.

105. I. Zweiniger-Bargielowska, Austerity in Britain: Rationing, Controls, and Consumption, 1939-1955 (Oxford, 2000).

106. Osgerby, "Roaring Twenties"; B. Conekin et al., Moments of Modernity: Reconstructing Britain 1945-1964 (London, 1999). For a different approach see S. Laing, Representations of Working-Class Life, 1957-1964 (Basingstoke, 1986). 
patterns, the treatment of youth and the operation of the family economy in the late I940s and early i950s had at least as much to do with people's responses to the possibility of and desire for economic and social change as it had to do with material developments across these years. Sons and daughters were imbued with "fantasies and dreams of grandeur", ${ }^{107}$ but bringing about material improvement - a watered down version of these dreams - required the same collective saving and spending strategies which had been needed in the I930s to make ends meet. Consequently, young wage-earners increasingly felt a tension between their aspirations, raised by family and education, and their emotional obligation to the parental household, frequently coupled with their financial inability to leave it.

This is captured in David Storey's semi-autobiographical portrayal of Colin Saville, a miner's son whose grammar-school education enables him to enter teaching in the late I940s. In the early I950s Colin is still living in the parental home though now it boasts "[a] new three-piece suite, the deposit paid as a result of his first month's salary [...] [and] a new diningtable". ${ }^{108}$ Colin, however, feels his own ambitions have been thwarted. His father is uncomprehending:

"We've given you a key to get out of this."

"I can't get out," [Colin] said. "You need the money. And in any case, with what I earn, I couldn't afford to live by myself." I09

As this suggests, youth was not a period of unlimited aspiration and consumption in the postwar decade. This helps make sense of another phenomenon which shaped the I950s - the falling age of marriage. In I93 I the average age of first marriage was twenty-five for women and twentyseven for men, but this began to fall from the late i 930 and continued to do so until the early I970s. One of the several reasons for this ${ }^{110}$ was young people's increasing ability to save for marriage, and particularly for a (usually rented) house. Oral histories indicate that parents allowed young wage-earners to retain a portion of their wages to save for a home of their own, and by the I950s this sum had become substantial. Trevor Jackson bought his first home with his new wife in 1956, when they were both

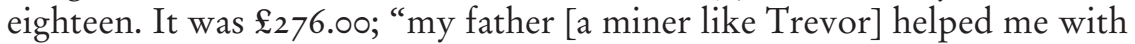
it", and his fiancée "worked - well she worked more than me actually" to accumulate the necessary funds. ${ }^{\text {II }}$ Elizabeth Roberts has documented the

I07. Walkerdine, "Dreams from an Ordinary Childhood", p. 72.

I08. D. Storey, Saville (London, I976), p. 442.

109. Ibid., p. 430.

I Iо. For a discussion of other factors see P. Thane, "Family Life and 'Normality' in Post-War British Culture", in R. Bessel and D. Schumann (eds), Life After Death: Approaches to a Cultural and Social History of Europe during the I940s and I950s (Cambridge 2003), pp. 198-199.

III. NWSA, 2000.0393, audio-cassette recorded interview with MN (Trevor Jackson is a pseudonym). 
importance of working-class parents in paying for weddings and domestic appliances for the newly-weds, contrasting this with the sparser beginnings to married life that were common in the I930s. ${ }^{\text {I2 }}$

The rosy image of i950s youth as a period of great financial and social independence implies a paradox here: why would people choose to marry young, thereby cutting short these golden years of independence? The popularity of marriage in the I950s is indicative of a widespread perception of youth as a transition period. The financial independence of the young wage-earner was not a sufficient incentive to postpone marriage, constrained as it was by parental and state supervision and low status and pay at work. Moreover, as the accounts of Trevor Jackson and David Storey suggest, the achievement of working-class affluence - as central to most postwar personal testimonies, as "making ends meet" is to narratives of earlier decades of working-class life ${ }^{\mathrm{II} 3}$ - rested on collective strategies for self-improvement, either in the parental home or elsewhere. Having a home of one's own was, as Langhamer has shown, imbued with status and independence both before and after World War II - but was increasingly realizable by the early i950s. ${ }^{\mathrm{II} 4}$ For most young working-class people, marriage remained the most viable and attractive financial and emotional opportunity for independence and status.

\section{CONCLUSION}

The mid-twentieth century provides an interesting case study of the disjuncture between the modern representation of youth as a period of protection and supervision and the economic importance of sons and daughters for many working-class families. This disjuncture frequently worked in the interests of many employers. It was promoted by interwar governments, and tacitly accepted by the postwar Labour government. Consequently, young working-class people remained an important source of cheap labour and their earnings continued to be crucial to the family economy. Class thus shaped their life experience, and not only economically: socially, their status was low and their consumption power constrained.

Gender was interrelated to class in ways that have only been touched on here. Young women were not expected to continue to work full-time after marriage and this affected the value placed on their education and training, particularly prior to World War II. However, both boys and girls made

I I 2. E. Roberts, Women and Families: An Oral History, 1940-1970 (Oxford, I995), pp. 72-75. II 3. On the importance of "making ends meet" to narratives of the interwar years, see Giles, Women, Identity and Private Life in Britain, pp. 90-95; Todd, Young Women, Work and Family, pp. I34-I44.

I 14. C. Langhamer, "The Meanings of Home in Postwar Britain”, Journal of Contemporary History, 40 (2005), pp. 347-349. 
significant contributions to the family economy, and this article has highlighted some important similarities in their experiences, opportunities, and the parental aspirations for and state expectations of them.

Young people's position as wage-earners shaped family relationships. Adult unemployment and the household means test of the r93os undermined the reciprocal relationships between young wage-earners and their parents, with negative material and emotional results. This helps explain the importance of interwar unemployment and welfare provision in structuring working-class political perspectives in the I940s. Postwar political, economic and social changes shifted the balance towards treating young people as dependants on the state as well as on the family. Workingclass parents' desire to give their children a better life materially, socially, and culturally was demonstrated by the substitution of married women for juveniles in the labour force, the granting of large amounts of spending money to sons and daughters, and the help given by parents to children in early married life. However, the limits of working-class affluence meant that young wage-earners remained important in achieving material aspirations and in keeping families that were larger than average, or housed no adult male breadwinners, out of poverty.

The disjuncture between young people's representation as dependants, and their importance to the family economy, is overlooked in popular, sociological, and historical representations of youth. These tend to present the affluent postwar teenager as a norm by which to judge other generations. This is evident in some of the personal testimonies cited here: it raises the consciousness of poverty which is integral to memories of interwar youth, and partly explains why testimonies of youth in the I950s concentrate more on consumption and affluence (either the getting of them or their absence) than those of earlier generations do. However, the affluent working-class teenager populated the social landscape for only a relatively brief period between the late i950s and early i970s. In twentieth-century England, being young and working-class was marked by the paradox of dependence, significant labour force participation, and increasing financial independence. This paradox is indicative of the tensions, as well as the connections, between state welfare provision, a capitalist labour market, and the maintenance of the family. It points to the connection between class and youth which makes this life-stage so significant within life histories. 


\section{APPENDIX}

Table 2. Regression analysis of determinants of girls' labour force participation rate

\begin{tabular}{|c|c|c|c|c|c|c|}
\hline \multicolumn{2}{|c|}{ Model } & \multicolumn{2}{|c|}{$\begin{array}{l}\text { Unstandardized } \\
\text { coefficients }\end{array}$} & \multirow{2}{*}{$\frac{\begin{array}{c}\text { Standardized } \\
\text { coefficients }\end{array}}{\text { Beta }}$} & \multirow[t]{2}{*}{$\mathrm{t}$} & \multirow[t]{2}{*}{ Sig. } \\
\hline & & $\mathrm{B}$ & Std. error & & & \\
\hline \multirow[t]{6}{*}{1} & (Constant) & -9.845 & 8.124 & & -1.212 & .229 \\
\hline & Dependency ratio & .338 & 1.287 & .016 & .263 & .793 \\
\hline & Juvenile ratio & 13.420 & 4.036 & .205 & 3.325 & .001 \\
\hline & $\begin{array}{l}\% \text { adult women in } \\
\text { labour force }\end{array}$ & .768 & .062 & .737 & 12.395 & .000 \\
\hline & $\begin{array}{l}\text { Male unemployment } \\
\text { rate }\end{array}$ & -.397 & .076 & -.297 & -5.245 & .000 \\
\hline & $\begin{array}{l}\% \text { boys in labour force } \\
(14-20)\end{array}$ & .665 & .080 & .467 & 8.350 & .000 \\
\hline \multirow[t]{18}{*}{2} & (Constant) & -1.867 & 15.812 & & -.118 & .906 \\
\hline & Dependency ratio & .566 & 1.392 & .027 & .407 & .685 \\
\hline & Juvenile ratio & 12.589 & 4.852 & .192 & 2.595 & .011 \\
\hline & $\begin{array}{l}\% \text { adult women in } \\
\text { labour force }\end{array}$ & .817 & .100 & .783 & 8.187 & .000 \\
\hline & $\begin{array}{l}\text { Male unemployment } \\
\text { rate }\end{array}$ & -.435 & .097 & -.325 & -4.464 & .000 \\
\hline & $\begin{array}{l}\text { \% boys in labour force } \\
(14-20)\end{array}$ & .514 & .154 & .361 & 3.345 & .001 \\
\hline & Males: agriculture & -.245 & .154 & -.133 & -1.593 & .115 \\
\hline & $\%$ Males: mining & $-7.19 \mathrm{E}-03$ & .061 & -.008 & -.118 & .906 \\
\hline & Males: metal & $3.956 \mathrm{E}-02$ & .066 & .039 & .601 & .549 \\
\hline & Males: textile & $1.545 \mathrm{E}-02$ & .133 & .012 & .116 & .908 \\
\hline & Males: textile goods & .182 & .127 & .086 & 1.430 & .156 \\
\hline & Males: wood/furniture & 1.057 & .378 & .179 & 2.797 & .006 \\
\hline & Males: building & $2.752 \mathrm{E}-02$ & .064 & .023 & .427 & .671 \\
\hline & $\begin{array}{l}\text { Males: transport/ } \\
\text { communication }\end{array}$ & $-9.21 \mathrm{E}-03$ & .031 & -.016 & -.294 & .769 \\
\hline & $\begin{array}{l}\text { Males: commerce/ } \\
\text { finance }\end{array}$ & $-7.09 \mathrm{E}-02$ & .241 & -.035 & -.294 & .769 \\
\hline & Males: professions & -.570 & .874 & -.095 & -.652 & .516 \\
\hline & Males: clerks & $9.219 \mathrm{E}-02$ & .169 & .037 & .544 & .588 \\
\hline & Males: unskilled & $5.783 \mathrm{E}-02$ & .146 & .030 & .397 & .692 \\
\hline
\end{tabular}

Model I: $\mathrm{R}^{2}=0.728$

Model 2: $\mathrm{R}^{2}=0.785$

Source: Census of England and Wales, I93I, "County Tables", London, I933; "Occupation Tables", London, I934.

Note: This table demonstrates that the dependency ratio was the only significantly influential variable on girls' labour force participation when adult male occupational variables were excluded. When these variables are added, mining exerts a significantly negative influence on labour force participation, while textiles exerts a significantly positive effect on their labour force participation. The reasons for and consequences of this are discussed in the text. 
Table 3. Regression analysis of determinants of boys' labour force participation rate

\begin{tabular}{|c|c|c|c|c|c|c|}
\hline \multicolumn{2}{|c|}{ Model } & \multicolumn{2}{|c|}{$\begin{array}{l}\text { Unstandardized } \\
\text { coefficients }\end{array}$} & \multirow{2}{*}{$\frac{\begin{array}{c}\text { Standardized } \\
\text { coefficient }\end{array}}{\text { Beta }}$} & \multirow[t]{2}{*}{$\mathrm{t}$} & \multirow[t]{2}{*}{ Sig. } \\
\hline & & B & Std. error & & & \\
\hline \multirow[t]{6}{*}{1} & (Constant) & 55.941 & 5.592 & & 10.004 & .000 \\
\hline & Dependency ratio & -.658 & 1.258 & -.044 & -.523 & .602 \\
\hline & Juvenile ratio & -11.429 & 4.006 & -.248 & -2.853 & .005 \\
\hline & $\begin{array}{l}\% \text { adult women in } \\
\text { labour force }\end{array}$ & -.477 & .085 & -.651 & -5.606 & .000 \\
\hline & $\begin{array}{l}\text { Male unemployment } \\
\text { rate }\end{array}$ & .400 & .073 & .426 & 5.454 & .000 \\
\hline & $\%$ girls in labour force & .637 & .076 & .906 & 8.350 & .000 \\
\hline \multirow[t]{18}{*}{2} & (Constant) & 82.733 & 5.490 & & 15.071 & .000 \\
\hline & Dependency ratio & .263 & .935 & .018 & .281 & .779 \\
\hline & Juvenile ratio & -8.615 & 3.251 & -.187 & -2.650 & .010 \\
\hline & $\begin{array}{l}\% \text { adult women in } \\
\text { labour force }\end{array}$ & -.110 & .089 & -.150 & -1.230 & .222 \\
\hline & $\begin{array}{l}\text { Male unemployment } \\
\text { rate }\end{array}$ & $2.146 \mathrm{E}-02$ & .073 & .023 & .295 & .769 \\
\hline & $\%$ girls in labour force & .231 & .069 & .329 & 3.345 & .001 \\
\hline & Males: agriculture & .403 & .095 & .311 & 4.236 & .000 \\
\hline & \% Males: mining & 7.972E-03 & .041 & .013 & .195 & .846 \\
\hline & Males: metal & $2.967 \mathrm{E}-02$ & .044 & .042 & .672 & .503 \\
\hline & Males: textile & $-5.07 \mathrm{E}-02$ & .089 & -.056 & -.569 & .571 \\
\hline & Males: textile goods & 7.429E-02 & .086 & .050 & .866 & .389 \\
\hline & Males: wood/furniture & -.132 & .265 & -.032 & -.497 & .621 \\
\hline & Males: building & $4.900 \mathrm{E}-02$ & .043 & .058 & 1.140 & .258 \\
\hline & $\begin{array}{l}\text { Males: transport/ } \\
\text { communication }\end{array}$ & $7.839 \mathrm{E}-04$ & .021 & .002 & .037 & .970 \\
\hline & $\begin{array}{l}\text { Males: commerce/ } \\
\text { finance }\end{array}$ & .242 & .160 & .170 & 1.515 & .134 \\
\hline & Males: professions & -3.941 & .399 & -.932 & -9.884 & .000 \\
\hline & Males: clerks & 8.177E-02 & .114 & .046 & .720 & .474 \\
\hline & Males: unskilled & .102 & .097 & .076 & 1.048 & .297 \\
\hline
\end{tabular}

Model I: $\mathrm{R}^{2}=0.472$

Model 2: $\mathrm{R}^{2}=0.804$

Source: Census of England and Wales, I93 I, "County Tables", London, I933; "Occupation Tables", London, I934.

Note: This table demonstrates that the dependency ratio was the only significantly influential variable on boys' labour force participation when adult male occupational variables were excluded. When these variables are added, those which exert a significant, positive influence on boys' labour force participation are mining and transport and communications. The reasons for and consequences of this are discussed in the text. 
Table 4. Regression analysis of determinants of adult women's labour force participation rate

\begin{tabular}{|c|c|c|c|c|c|c|}
\hline \multicolumn{2}{|c|}{ Model } & \multicolumn{2}{|c|}{$\begin{array}{l}\text { Unstandardized } \\
\text { coefficents }\end{array}$} & \multirow{2}{*}{$\begin{array}{c}\begin{array}{c}\text { Standardized } \\
\text { coefficients }\end{array} \\
\text { Beta }\end{array}$} & \multirow[t]{2}{*}{$\mathrm{t}$} & \multirow[t]{2}{*}{ Sig. } \\
\hline & & B & Std. error & & & \\
\hline \multirow[t]{6}{*}{1} & (Constant) & 25.716 & 7.954 & & 3.233 & .002 \\
\hline & Dependency ratio & -2.159 & 1.299 & -.106 & -1.663 & .100 \\
\hline & Juvenile ratio & -17.444 & 3.981 & -.277 & -4.382 & .000 \\
\hline & $\begin{array}{l}\text { Male unemployment } \\
\text { rate }\end{array}$ & .349 & .080 & .272 & 4.344 & .000 \\
\hline & $\%$ girls in labour force & .805 & .065 & .839 & 12.395 & .000 \\
\hline & $\begin{array}{l}\text { \% boys in labour force } \\
(14-20)\end{array}$ & -.521 & .093 & -.382 & -5.606 & .000 \\
\hline \multirow[t]{18}{*}{2} & (Constant) & -6.982 & 12.921 & & -.540 & .590 \\
\hline & Dependency ratio & -1.870 & 1.122 & -.092 & -1.667 & .099 \\
\hline & Juvenile ratio & $5.775 \mathrm{E}-03$ & 4.129 & .000 & .001 & .999 \\
\hline & $\begin{array}{l}\text { Male unemployment } \\
\text { rate }\end{array}$ & .250 & .084 & .195 & 2.960 & .004 \\
\hline & $\%$ girls in labour force & .547 & .067 & .570 & 8.187 & .000 \\
\hline & $\begin{array}{l}\% \text { boys in labour force } \\
(14-20)\end{array}$ & -.163 & .133 & -.120 & -1.230 & .222 \\
\hline & Males: agriculture & -.114 & .127 & -.065 & -.899 & .371 \\
\hline & \% Males: mining & $2.725 \mathrm{E}-02$ & .050 & .033 & .546 & .586 \\
\hline & Males: metal & $1.458 \mathrm{E}-02$ & .054 & .015 & .270 & .788 \\
\hline & Males: textile & .540 & .091 & .434 & 5.911 & .000 \\
\hline & Males: textile goods & .120 & .104 & .059 & 1.147 & .255 \\
\hline & Males: wood/furniture & -.579 & .317 & -.102 & -1.825 & .072 \\
\hline & Males: building & $-5.39 \mathrm{E}-02$ & .053 & -.047 & -1.027 & .308 \\
\hline & $\begin{array}{l}\text { Males: transport/ } \\
\text { communication }\end{array}$ & $-1.63 \mathrm{E}-02$ & .026 & -.029 & -.638 & .525 \\
\hline & $\begin{array}{l}\text { Males: commerce/ } \\
\text { finance }\end{array}$ & .535 & .188 & .276 & 2.843 & .006 \\
\hline & Males: professions & .961 & .710 & .166 & 1.354 & .180 \\
\hline & Males: clerks & -.163 & .138 & -.067 & -1.181 & .241 \\
\hline & Males: unskilled & $-2.37 \mathrm{E}-02$ & .119 & -.013 & -.198 & .843 \\
\hline
\end{tabular}

Model I: $\mathrm{R}^{2}=0.690$

Model 2: $\mathrm{R}^{2}=0.844$

Source: Census of England and Wales, I931, "County Tables", London, I933; "Occupation Tables", London, I934.

Note: This table demonstrates that when adult male occupational variables are excluded from the analysis, no variables exert a significant influence on women's labour force participation. When adult male occupational variables are added, the juvenile ratio exerts a negative, significant influence on adult women's labour force participation. The reasons for and consequences of this are discussed in the text. 